\title{
Makroalga di Daerah Intertidal Pulau Lombok Bagian Selatan
}

\author{
$\operatorname{Karnan}^{1 *}$, Didik Santoso ${ }^{1}$, Lalu Japa ${ }^{1}$, Ahmad Raksun $^{1}$ \\ ${ }^{1}$ Program Studi Pendidikan Biologi FKIP Universitas Mataram \\ *Email:karnan.ikan@unram.ac.id
}

Diterima: 8 Mei 2018 Publish: 30 Juni 2018

\begin{abstract}
Abstrak
Macroalga adalah sumber daya penting tidak hanya untuk komunitas intertidal, tetapi juga untuk manusia, seperti makanan, kosmetik, dan farmasi. Hal ini lebih mungkin bahwa sebagai bagian dari daerah tropis, zona intertidal Lombok memiliki keragaman makroalga yang tinggi. Sayangnya, keberadaan biota ini, terutama di daerah ini, sedikit diketahui. Makalah ini menggambarkan keanekaragaman hayati dan keadaan makroalga di Zona Intertidal Selatan Pulau Lombok. Informasi tentang keberadaan biota ini sangat membantu pemerintah dan masyarakat untuk mendapatkan sumber senyawa baru yang berharga yang diperlukan untuk kehidupan kita
\end{abstract}

Kata kunci: zona intertidal, Lombok, makroalga.

\begin{abstract}
Macroalga is an important resources not only for intertidal communities, but also for human, such as food, cosmetic, and pharmacy. It is more likely that as a part of tropical area, intertidal zone of Lombok has a high diversity of macroalga. Unfortunately, the existency of this biota, mainly in this area, are litle known. This paper describe the biodiversity and state of macroalga in the Southern Intertidal Zone of Lombok Island. Information on the existency of this biota is very helpful for government and community to obtain new other valuable compound sources required for our life.
\end{abstract}

Key words: intertidal zone, Lombok, macroalga. 


\section{Pendahuluan}

Makroalga merupakan salah satu kekayaan spesies yang sangat penting, tidak hanya bagi masyarakat pe s is ir, tetapi juga dalam dunia kesehatan pada umumnya. Wilayah Nusa Tenggara Barat merupakan wilayah yang memiliki potensi sangat besar dalam pengembangan alga, khususnya rumput laut. Hal ini dibuktikan dengan telah ditetapkannya program pengembangan sapi, jagung, dan rumput laut (PIJAR) sebagai program unggulan daerah (Pemprov NTB, 2009). Beberapa jenis senyawa yang diekstrak dari alga dilaporkan memiliki akitivitas sebagai anti kanker, misalnya kahalalide $\mathrm{F}$ dari alga Bryopsis, $\beta$-karoten dari alga Rhodymenia pseudopalmata, Eucheuma serra agglutinin (ESA), fraksi protein dari alga merah, Euchema spinosum, serta ekstrak kasar fucoidan yang diisolasi dari alga coklat Sargassum polycystum (Smith, 2004).

Karnan et al (2016) menyatakan bahwa secara ekologis, kompleksitas yang dibentuk oleh komunitas Sargassum ini memiliki fungsi yang sama dengan terumbu karang, padang lamun, dan mangrove yaitu sebagai daerah asuhan (nursery ground), tempat mencari makan (feeding ground), tempat memijah (spawning ground) dan meletakkan telur bagi berbagai macam biota laut seperti ikan dan cumi-cumi. Keberadaan komunitas Sargassum ini dapat pula meredam kecepatan arus sehingga berperan penting dalam penyelamatan pantai. Selain itu komunitas Sargasum dapat berperan untuk meningkatkan nilai biodiversity dan peran ini sangat penting seperti peran ekologi lamun.

Dari uraian di atas, seharusnya potensi sumber daya alam kita yang sangat strategis seperti alga ini seharusnya sudah dikenal baik oleh masyarakat. Secara umum, pengetahuan kita tentang sumber daya laut, termasuk makroalga masih sangat terbatas. Beberapa penyebab terjadinya kondisi ini adalah kajian dan laporan tentang keberadaan makroalga di wilayah ini masih sangat terbatas. Tulisan ini mendeskripsikan kondisi spesies makroalga yang ditekankan kepada keanekaragaman dan statusnya di kawasan intertidal bagian selatan pulau Lombok, Nusa Tenggara Barat.

\section{Bahan dan Metode}

Pengambilan sampel dilakukan pada daerah intertidal di Perairan pantai selatan Pulau, Lombok, yaitu di kawasan 
Kaliantan (Lombok Timur); teluk Serinting (Lombok Tengah); dan teluk Batukijuk (Lombok Barat) pada bulan Agustus - Septemer 2017. Makroalga merupakan komunitas tumbuhan bentik yang hidup di daerah intertidal. Karena itu, untuk mendapatkan sampel yang memadai, pengambilan sampel dilakukan pada saat air laut mengalami surut terjauh. Langkah-langkah pelaksanaan penelitian ini merupakan modifikasi dari English et al,. (1995).

Secara berurutan, pelaksanaan penelitian dilakukan dengan langkahlangkah sebagai berikut: a. Menentukan letak stasiun di masing-masing lokasi (Lombok Timur, Lombok Tengah, dan Lombok Barat); b. Membuat garis transek dengan arah tegak lurus garis pantai. Garis transek dibuat dengan menggunakan meteran gulung (roll meter). Penentuan jumlah garis transek dilakukan dengan mempertimbangkan luas dan karakteristik wilayah intertidal di masing-masing lokasi. c. Di sebelah kiri dan kanan garis transek diletakkan kuadrat (berukuran 1x1 meter) sebagai titik pengamatan. Jarak antara kuadrat yang satu dengan kuadrat berikutnya ditentukan yakni 10 meter. d. Makroalga yang ditemukan di setiap kuadrat dijadikan sampel yang selanjutnya diidentifikasi jenis dan jumlah tegakan masing-masing jenis.

Identifikasi dilakukan berdasarkan ciri-ciri dan morfologinya dengan mengacu pada Fuhrer et al (1988); Gakken (1975); Juwana (2007); Wattimury (2004); Kader (2005). Setiap jenis makroalga yang didapatkan difoto untuk mempermudah dalam melakukan validasi berikutnya bila terjadi kesulitan dalam melakukan identifikasi di lapangan, beberapa jenis makroalga yang ditemukan dibawa ke Laboratorium Pendidikan MIPA FKIP Universias Mataram untuk diidentifikasi.

Komposisi spesies adalah perbandingan antara jumlah individu setiap spesies dengan jumlah individu seluruh spesies yang tertangkap, dengan formula:

$$
K s=\frac{n_{i}}{N} \times 100 \%
$$

dimana:

$\mathrm{Ks}=$ Komposisi spesies makroalga (\%), $\mathrm{ni}=$ Jumlah individu setiap spesies makroalga,

$\mathrm{N}=$ Jumlah individu seluruh spesies makroalga.

Struktur komunitas makroalga yang dianalisa meliputi Indeks Dominansi, Indeks Keanekaragaman dan Indeks Keseragaman. Nilai indeks Dominansi memberikan gambaran 
tentang dominansi makroalga dalam suatu komunitas ekologi, yang dapat menerangkan bilamana suatu spesies makroalga lebih banyak terdapat selama pengambilan data, dengan formula Margalef (1958) dalam odum (1983):

$$
C=\sum\left(\frac{n_{i}}{N}\right)^{2}
$$

dimana:

$\mathrm{C}=$ Indeks Dominansi Simpson,

$\mathrm{N}=$ Jumlah individu seluruh spesiesies,

ni $=$ Jumlah individu dari spesies

makroalga ke-i.

Indeks keanekaragaman adalah nilai yang dapat menunjukkan keseimbangan keanekaragaman dalam suatu pembagian jumlah individu tiap spesies. Sedikit atau banyaknya keanekaragaman spesies makroalga dapat dilihat dengan menggunakan indeks keanekaragaman. Indeks keanekaragaman mempunyai nilai terbesar jika semua individu berasal dari spesies yang berbeda-beda. Sedangkan nilai terkecil didapat jika semua individu berasal dari satu satu spesies saja (Odum, 1983). Nilai indeks keanekaragaman Shannon (H') menurut Shannon and Wiener (1949) dalam Odum (1983) dihitung menggunakan formula :

$$
H^{\prime}=-\sum p_{i,} \ln _{p i}
$$

dimana :

$\mathrm{H}^{\prime}=$ Indeks Keanekaragaman, pi $=$ Proporsi jumlah individu $(\mathrm{ni} / \mathrm{N})$.
Nilai Indeks keseragaman (E), semakin besar menunjukkan kelimpahan yang hampir seragam dan merata antar spesies. Formula dari indeks keseragaman (Odum,1983) yaitu:

$$
E=\frac{H^{\prime}}{\log S}
$$

dimana :

$\mathrm{E}=$ Indeks Keseragaman

$\mathrm{H}^{\prime}=$ Indeks Keanekaragaman

$\mathrm{S}=$ Jumlah spesies

Untuk mengetahui tingkat pengelompokkan berdasarkan kesamaan spesies dan kondisi ekologis makroalga di lokasis penelitian secara temporal digunakan Indeks Bray

- Curtis (Bray - Curtis Similarity)

dengan formula :

$$
I B=\frac{\left(x_{I J}-X_{i k}\right)}{\left(I_{i j}-X_{i k}\right)} \times 100 \%
$$

dimana :

$I B=$ Nilai Kesamaan Indeks BrayCurtis,

$\mathrm{X}_{\mathrm{ij}}, \mathrm{X}_{\mathrm{ik}}=$ Nilai spesies ke-i lokasi yang berbeda.

Hasil perhitungan indeks Bray-Curtis ditampilkan dalam bentuk dendogram. 


\section{Hasil dan Pembahasan}

\section{Komposisi Spesies}

Secara keseluruhan ditemukan ada 22 jenis makroalga yang tersebar di seluruh lokasi penelitian. Gambar 1 menyajikan komposisi spesies makroalga di masing-masing lokasi penelitian tahun 2017. Komposisi spesies makroalga yang ditemukan di setiap lokasi penelitian berkisar antara 4-11 spesies. Jumlah spesies terendah ditemukan di Serinting_2, suatu lokasi pengamatan di Pantai Selatan Lombok Tengah (4 spesies). Sementara itu, spesies makroalga yang terbanyak ditemukan di perairan pantai Kaliantan, Lombok Timur (11 spesies).

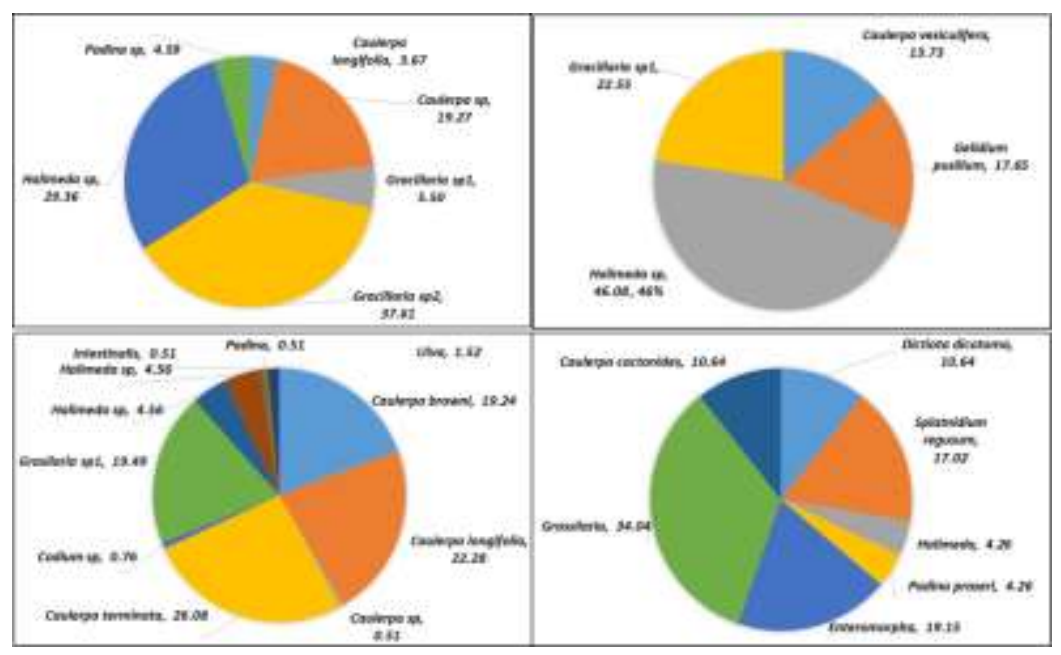

Gambar 1. Komposisi spesies makroalga di perairan pantai pulau Lombok bagian selatan tahun 2017 (A: Serinting_1; B: Serinting_2; C: Kaliantan, dan D: Sekotong)

Studi tentang berbagai aspek Kulon, Banten (Handayani, et al., 2009). makroalga telah dilakukan di beberapa Di Pantai Pidakan, Pacitan, ditemukan 15 lokasi, baik dari sudut keanekaragaman maupun analis manfaatnya. Jumlah spesies yang ditemukan di lokasi penelitian kali ini mirip dengan jumlah yang ditemukan di lokasi lain di Indonesia. Sebagai contoh, Oryza et al., (2016) menemukan makroalga yang terdapat di daerah intertidal Pantai Pasir Panjang, Malang ada 21 jenis. Telah berhasil dicatat pula ada 14 spesies makroalga di perairan Pantai Paniis Ujung spesies alga makro yang tersebar pada 90 plot dan 15 transek (Setyawan, et. al.,2014). Kondisi yang ditemukan di lokasi penelitian kali ini dan lokasi lain di Indonesia sebagaimana yang dilaporkan tersebut, berbeda jauh dengan hasil pengamatan yang dilaporkan Sukiman et al., (2014) bahwa di perairan Sekotong Lombok Barat terdapat 61 spesies makroalga (Sukiman, et al., 2014). Bahkan, di perairan Indonesia bagian 
timur ditemukan kondisi yang jauh lebih rendah. Sinyo dan Sumadayo (2013) melaporkan kondisi keanekaragaman makroalga di wilayah Indonesia bagian timur, yakni di Perairan Pantai Pulau Dofamuel Sidangoli, Halmahera Barat hanya tercatat 9 jenis makro alga. Di kawasan Afrika, Coppejans et al., (1999) melaporkan ada 48 spesies Rhodophyta, 10 spesies Phaeophyta dan 38 spesies Chlorophyta di perairan Kenya dan Tanzania.

Arfah dan Patty (2014) menguraikan bahwa pertumbuhan rumput laut yang baik umumnya terdapat pada daerah yang bersubstrat pasir dengan tutupan lamun yang tinggi. Ahli lain, Figueiredo dan Creed (2017) menjelaskan bahwa distribusi spesies alga laut tidak hanya dipengaruhi oleh suhu sebagai akibat letak bujur, tetapi juga oleh isolasi secara geografis. Keberadaan spesies alga tertentu di suatu lokasi bisa diakibatkan oleh pergerakan arus. Di lokasi penelitian, isolasi secara geografis dan pola pergerakan arus diduga sebagai faktor pengendali distribusi makroalga. Sebagaimana diketahui bahwa lokasi sampling di Sekotong (Pantai Batu Kijuk) merupakan lokasi yang dekat dengan perkampungan penduduk dan berbagai aktivitas masyarakat, terutama wisatawan lokal. Begitu pula halnya dengan pantai Serinting yang dikenal merupakan rataan terumbu yang cukup luas (>100 meter dari garis pantai). Arfah dan Patty (2014) mengatakan bahwa kerusakan terumbu karang dan padang lamun akan berpengaruh terhadap penurunan pertumbuhan, keanekaragaman jenis, dominasi dan biomassa makro algae di perairan Teluk Kotania.

Makroalga telah lama dimanfaatkan penduduk pantai yang di gunakan sebagai bahan pangan dan obatobatan. Sebagai bahan pangan, rumput laut umumnya di buat lalapan (dimakan mentah), urap (bumbu kelapa di parut), acar atau asinan (bumbu cuka), selain itu masyarakat pesisir bisa menggunakanya sebagai obat luar seperti antiseptik dan pemeliharaan kulit. Guiry dan Guiry (2007) menyebutkan bahwa beberapa jenis makroalga laut dapat dimakan, yaitu Undaria pinnatifida, Laminaria (alga coklat), Porphyra (alga merah), serta Ulva dan Enteromorpha (alga hijau).

Saat ini pemanfaatan rumput laut telah mengalami kemajuan yang sangat pesat. Alga dapat digunakan sebagai minyak biodiesel, bioethanol, biobuthanol, dan gas hidrogen (Raja, et al., 2013). Di perairan sekitar pulau Lombok, Widyastuti (2008) menganalisis kandungan karagenan alga coklat dimana kandungan karagaenan yang didapatkan 
adalah $0,75 \%$ (Turbinaria ornata) dan $6,92 \%$ (Dictyota sp1). Selain itu, Widyastuti (2010) juga telah mengkaji sifat fisik dan kimiawi karagenan hasil ekstraksi dari rumput laut Eucheuma cottonii dan E. spinosum yang dipanen pada waktu berbeda di perairan Pulau Lombok. Selain dimakan dan dimanfaatkan dalam bidang farmasi, makroalga, yang meliputi: Sargassum sp.1, Sargassum sp.2, Sargassum polycistum, Hydroclathrus sp., Turbinaria ornata, and Turbinaria murayana juga dapat dimanfaatkan sebagai pupuk dalam budidaya padi dan jenis tanaman lainnya (Sunarpi, et al (2010).

Selain di gunakan untuk pengobatan langsung, olahan makroalga juga dapat dijadikan agar-agar, algin, keraginan (carrageenan), dan furselaran (furcellaran) yang merupakan bahan baku penting dalam industri makanan, farmasi, kosmetik dan lain-lain (Kordi, 2010).

Dalam kehidupan di laut, makroalga memiliki peranan secara ekologis. Selain itu, makroalga juga telah digunakan sebagai sumber makanan dan obat-obatan (Coppejans et al., (1999). Beberapa spesies makroalga dikenal tidak hanya sebagai penyedia bahan makanan, tetapi juga memproduksi ekstrak yang digunakabn sebagai bahan makanan, farmasi, kecantikan, dan industri lainnya.

\section{Keanekaragaman, Dominansi, dan Keseragaman}

Gambar 2 menyajikan secara ringkas besaran indeks ekologis yang meliputi indeks keanekaragaman, dominansi, dan keseragamanan makroalga di masing-masing lokasi pengamatan. Indeks keanekaragaman yang didapatkan di 4 stasiun berkisar antara 1,27 - 1,78 (Gambar 2A), sedangkan indeks dominansi berkisar antara 0,20 - 0,31. Sementara itu, indeks keseragaman berkisar antara 1,71 - 2,11. Keanekaragaman jenis tertinggi dijumpai di stasiun Kaliantan, Lombok Timur $(1,78)$ dan terendah di Stasiun Serinting_2, Lombok Tengah. Sebagaimana yang dikemukakan sebelumnya bahwa di lokasi penelitian ini secara keseluruhan ditemukan 22 jenis makroalga. Di Kaliantan sendiri memiliki kekayaan spesies makroalga tertinggi, yakni 11 jenis, sedangkan di Serinting_1 dan Serinting_2 hanya memiliki kekayaan jenis masing-masing 6 dan 4 jenis; serta Sekotong 7 jenis. 


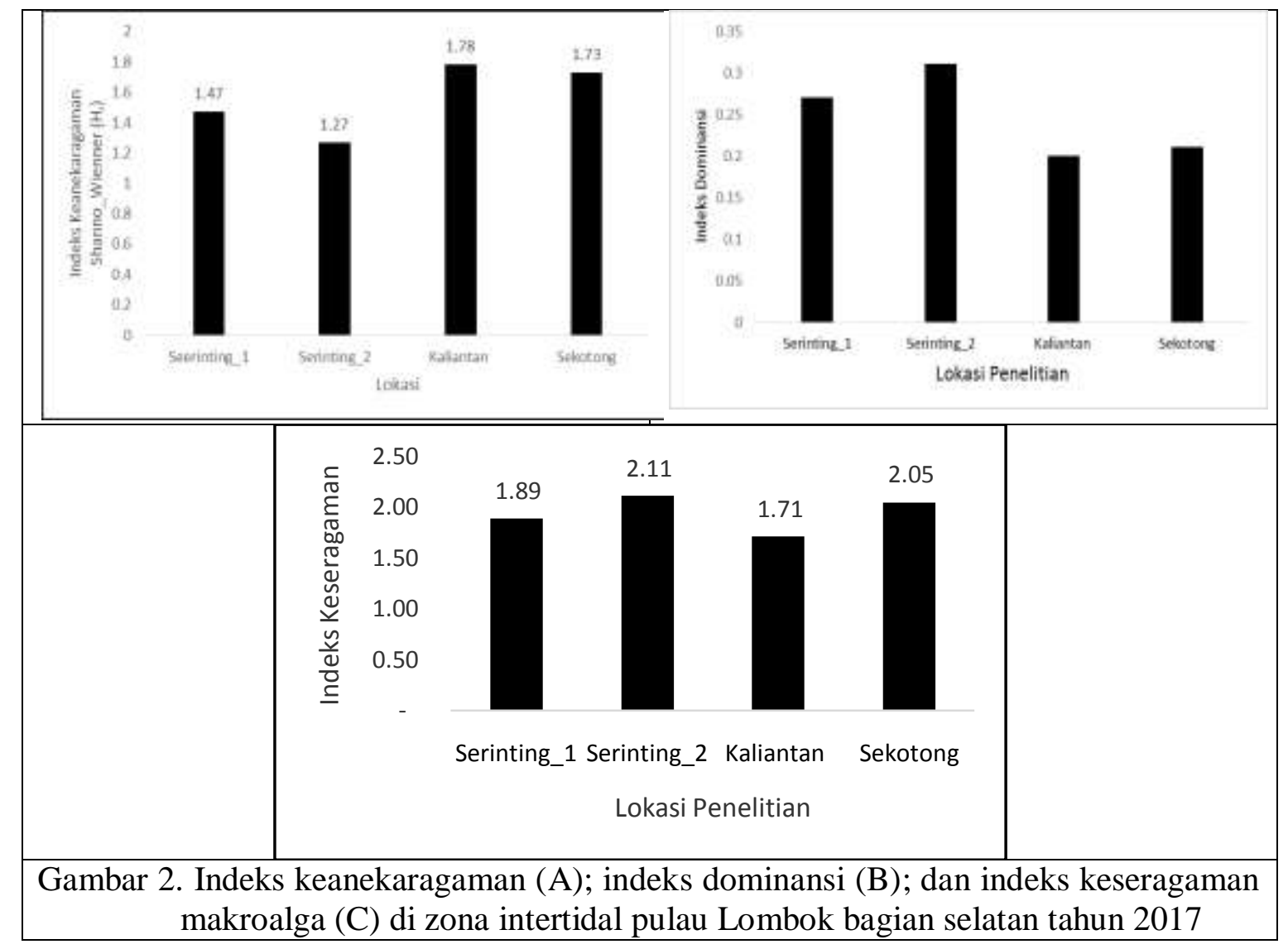

Hasil penelitian ini tidak berbeda jauh dengan hasil penelitian yang dilakukan di lokasi lain di perairan Indonesia. Kadi (2006) melaporkan bahwa keanekaragaman jenis $\left(H^{\prime}\right)$ makroalga di perairan pulau Pengelap, Riau sebesar 1,904 dan indeks kemerataan $(E)$ 1,662 dengan kekayaan jenis makroalgae seluruhnya berjumlah 24 jenis.

\section{Persentase Penutupan}

Gambar 3 menyajikan rataan persentase pentupan makroalga di masing-masing stasiun penelitian. Dari Gambar ini terlihat bahwa rataan persentase penutupan makroalga tertinggi ditemukan di Kaliantan, Lombok Timur. Kondisi ini seiring dengan jumlah jenis dan tingkat keanekaragaman yang dikemukakan di atas bahwa Kaliantan memiliki kondisi terbaik dibandingkan dengan lokasi pengamatan lainnya. 


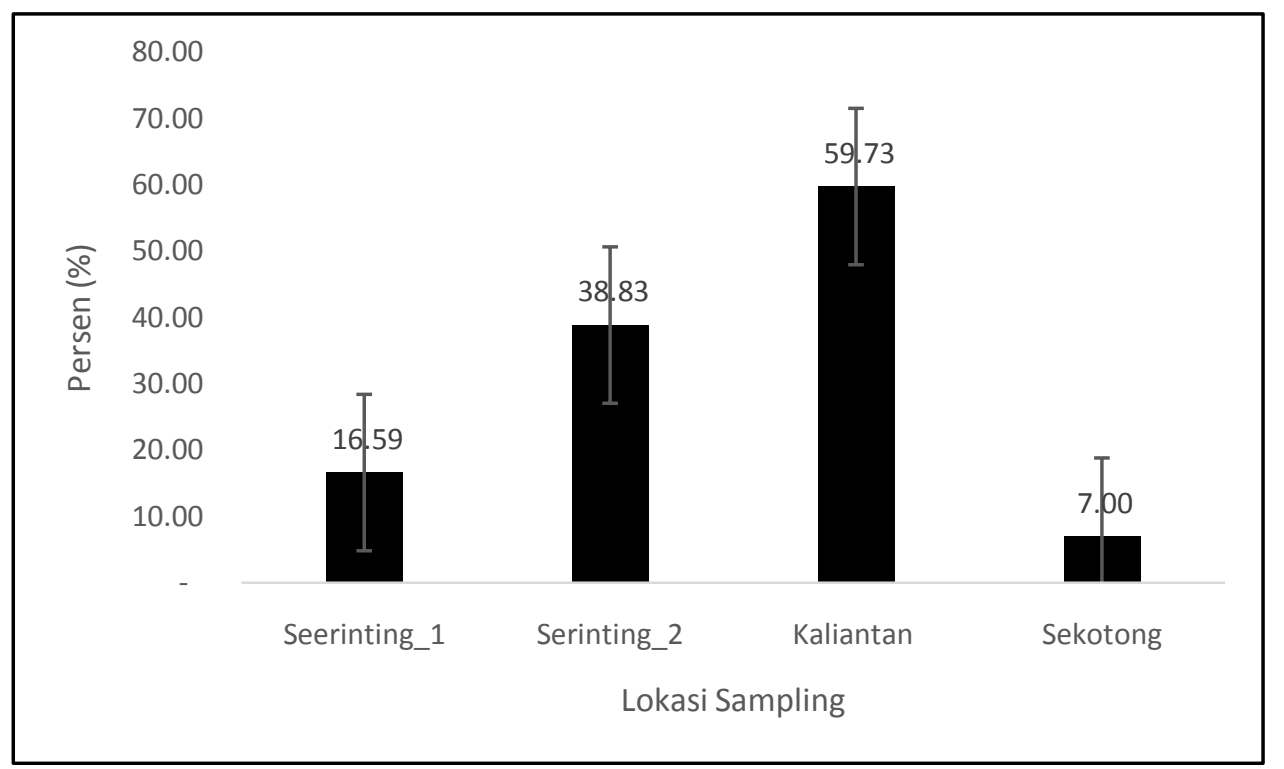

Gambar 3 Rataan persentase penutupan makroalga di lokasi penelitian tahun 2017

Dari Gambar 3 di atas juga terlihat bahwa stasiun Sekotong memiliki persentase penutupan terendah $(7,00$ \%). Ada beberapa faktor yang berpengaruh terhadap pertumbuhan komunitas pantai dimana makroalga ada di dalamnya. Salah satu faktor yang dapat dilihat dengan mata adalah aktivitas manusia (penduduk). Sebagaimana diketahui bahwa semua lokasi penelitian ini merupakan zona intertidal yang mudah dijangkau oleh manusia. Berbagai aktivitas manusia dapat berlangsung di daerah intertidal, misalnya mencari biota yang terperangkap di zona intertidal untuk dikonsumsi, atau hanya sekedar berwisata di lokasi ini. Telah diketahui pula bahwa daratan di sekitar Sekotong merupakan lokasi penambangan emas sedara liar yang berdampak terhadap kualitas air di sekitarnya yang selanjutnya akan mempengaruhi komunitas di daerah litoral.

Uraian di atas sejalan dengan pernyataan Orth et al (2006) bahwa faktor utama yang berperan dalam keruskanan padang lamun adalah kerusakan yang disebabkan oleh aktivitas manusia, seperti pembangunan di pantai dan penurunan kualitas air. Sementara itu, Patty (2016) mengatakan bahwa kerusakan ekosistem lamun, antara lain, karena reklamasi dan pembangunan fisik di garis pantai, pencemaran, penangkapan ikan dengan cara destruktif (bom, sianida, pukat dasar), dan tangkap lebih (over-fishing). 


\section{Kemiripan kondisi antar lokasi pengamatan}

Berdasarkan

kondisi

makroalga yang diuraiakan di atas terlihat adanya kemiripan kondisi diantara masing-masing lokasi pengamatan. Gambar $\quad 4$ menggambarkan kemiripan di antara lokasi pengamatan berdasarkan kondisi kesamaan spesies dan ekologis makroalga di lokasi penelitian.

Broy-Cuns Clester Anaysis fBingle Linis

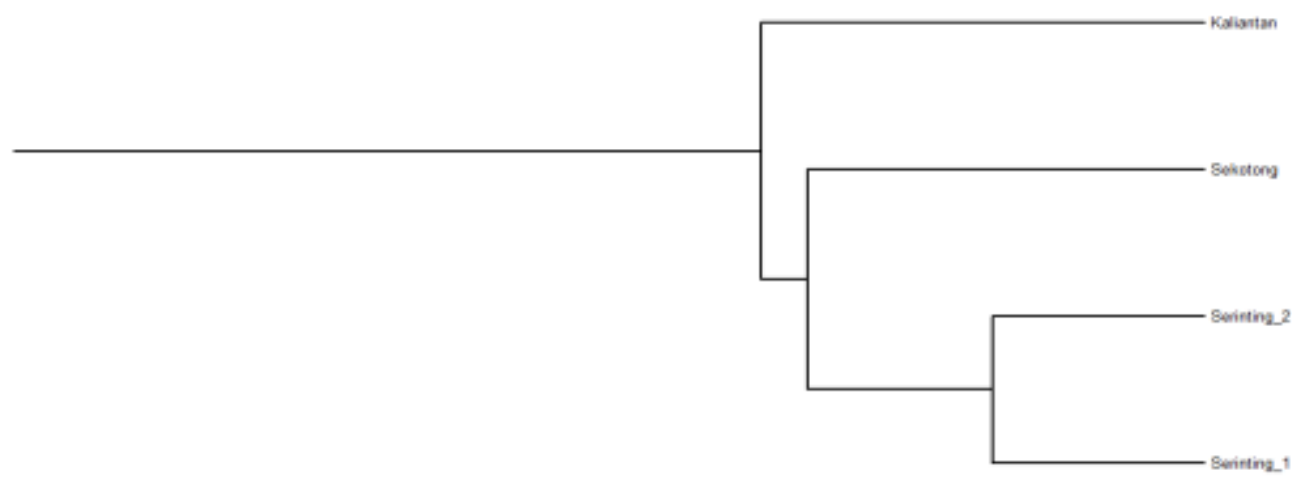

a. 5 simisity

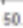

Gambar 4 Output analisis klaster berdasarkan keanekaragaman, dominanasi, kesamaan dan persentase penutupan makroalga di lokasi penelitian tahun 2017

Dari Gambar 4 di atas terlihat ada pengelompokan yang jelas di antara stasiun pengamatan. Paling tidak terjadi dua kelompok besar yaitu Kaliantan Lombok Timur dan stasiun Serinting di Lombok Tengah dan Sekotong, Lombok Barat. Stasiun Kaliantan, Lombok Timur, tampak terpisah dengan tiga stasiun lainnya. Hal ini terjadi karena kondisi makroalga di Kaliantan terbaik dibandingkan dengan lokasi lain. Sementar itu, stasiun Sekotong memiliki kemiripan dengan stasiun Serinting, Lombok Tengah.

Keberadaan stasiun Serinting (1 dan 2) dan Sekotong yang berada dalam satu kelompok terjadi karena kemiripan kondisi yang ada. Sebagaimana diketahui bahwa kawasan pantai Selatan Pulau Lombok, teruama kawasan Kuta, Serinting dan sekitarnya telah ditetapkan pemerintah pusat sebagai Kawasan Ekonomi Khusus (KEK). Kegiatan konstruksi yang sedang 
berlangsung secara besar-besar yang terus berlangsung dapat mempengaruhi kualitas air di kawasan ini yang selanjutnya dapat berdampak terhadap kehidupan komunitas intertidal. Kondisi yang serupa juga terjadi di perairan Sekotong, Lombok Barat. Hanya saja kalau di Lombok Barat, penyebabnya adalah aktivitas penambangan tanpa izin (PETI).

\section{Kesimpulan}

Berdasarkan hasil yang didapatkan, maka dapat disimpulkan bahwa: ada 22 jenis makroalga penghuni daerah intertidal di kawasan pesisir pulau Lombok bagian selatan dengan tingkat keanekaragaman yang rendah; faktor aktivitas manusia, terutama kegiatan konstruksi di daratan sekitar pantai dan penambangan emas tanpa izin (PETI) diduga sebagai penyebab utama rendahnya keanekaragaman makroalga di lokasi penelitian.

\section{Daftar Pustaka}

Arfah, H dan S.I. Patty. 2014. Keanekaragaman Dan Biomassa Makro Algae di Perairan Teluk Kotania, Seram Barat. Jurnal Ilmiah Platax 2 (2): 63-73 (http://ejournal.unsrat.ac.id/inde x.php/platax. Diakses: 2 Desember 2017).

Coppejans, E., F. Leliaert., dan O. De Clerck. 1999. Annotated List Of New Records Of Marine Macroalgae For Kenya And
Tanzania, Since Isaac's And Jaasund's Publications. BioI. Jaarb. Dodonaea, 67 (1) : 3193.

English, S., Wilkinson, C., \& Baker, V. 1994. Survey Manual for Tropical Marine Resources 2nd. Townville: Australia Institut of Marine Science.

Figueiredo, M. A. O dan J. C. Creed. 2017. Marine Algae and Plants. Tropical biology and conservation management Vol. IV (http://www.eolss.net/ebooklib/s c_cart.aspx?File=E6-142-TB09). Diakses: 2 Desember 2017.

Fuhrer, B., M.N. Clayton., and B. M. Allender. 1988. Seaweed of Australia. Reed Book Pty Ltd. Sydney, NSW.

Gakken. 1975. Illustrated Nature the Seaweed of Japan. Gakken Ltd Japan.

Guiry MD, Guiry GM. 2007. AlgaeBase version 4.2. World-wide electronic publication. Galway: National Univ. Ireland. http://www.algaebase.org. Diakses. Agustus 2017.

Handayani, S, P. Rahayu, A. Rachmawati dan S. Aisyah. 2009. Keanekaragaman Makro alga di Pantai Paniis Ujung Kulon, Banten. Ilmu Dan Budaya 29, No.17, April 2009: 1650-1658.

Juwana. 2007. Teknologi Benih Rumput Laut dan Bobot Benih. Jakarta.

Kader, I. 2005. Struktur Komunitas Makro Alga Di Perairan Guraici, Kabupaten Halmahera Selatan. (Tesis). Program 
Pascasarjana UNSRAT Manado.

Kadi, A. 2006. Struktur Komunitas

Makro Algae di Pulau

Pengelap, Dedap, Abang Besar dan Abang Kecil \& Kepulauan Riau. Ilmu Kelautan. 11 (4):

$234-240$.

Karnan, Al Idrus, A., dan Japa, L. 2016. Laju Pertumbuhan Sargassum yang Dibudidaya di Teluk Ekas Lombok Timur. Prosiding Seminar Nasional Pertanian Universitas Mataram, 12 November 2016

Kordi, K. 2008. Budidaya Perairan Edisi ke- 1. Bandung.

Odum, E.P. (1983). Dasar-dasar Ekologi. Edisi ketiga.

Yogyakarta: Gajah Mada University, press.

Orth, R.J., Carruthers, T.J.B., Dennison, W.C., Duarte, C.M., Fourqurean, J.W., Heck Jr., K.L., Hughes, A.R., Kendrick, G.A., Kenworthy, W.J., Olyarnik, S., Short, F.T., Waycott, M., and Williams, S.L. 2006. A global crisis for seagrass ecosystems. BioScience 56: 987-996.

Oryza, D., S. Mahanal, dan M. Saptasari. 2016. Keanekaragaman Makroalga Di Daerah Intertidal Pantai Pasir Panjang Kabupaten Malang. Seminar Nasional Pendidikan dan Saintek 2016: 456-463.

Patty, S. I. 2016. Pemetaan kondisi padang lamun di perairan Ternate, tidore dan sekitarnya. Jurnal Ilmiah Platax 4 (1): 918.

(http://ejournal.unsrat.ac.id/inde x.php/platax. Diakses Desember 2017).
Pemerintah Provinsi Nusa Tenggara

Barat. 2009. Sapi Jagung

Rumput Laut

(PIJAR).Pemerintah Provinsi

Nusa Tenggara Barat. Mataram.

53 hal.

Raja, A. C. Vipin and A.Aiyappan. 2013. Biological importance of Marine Algae: An overview. Int.J.Curr.Microbiol.App.Sci (2013) 2(5): 222-227. Diakses Desember 2017.

Setyawan. I.B., W. Prihanta, dan E. Purwanti. 2014. Identifikasi keanekaragaman dan pola penyebaran makroalga di daerah pasang surut pantai pidakan Kabupaten Pacitan sebagai sumber belajar biologi. Jurnal Pendidikan Biologi Indonesia volume 1(1): 78-88.

Sinyo, W dan N. Sumadayo. 2013. Studi Keanekaragaman Jenis Makroalga Di Perairan Pantai Pulau Dofamuel Sidangoli Kecamatan Jailolo Selatan Kabupaten Halmahera Barat. Jurnal Bioedukasi 1 (2): 120-130.

Sinyo, Y dan N. Sumadayo. 2013. Studi Keanekaragaman Jenis Makroalga Di Perairan Pantai Pulau Dofamuel Sidangoli Kecamatan Jailolo Selatan Kabupaten Halmahera Barat. Jurnal Bioedukasi 1 (2): 120-130.

Smith, A.J., 2004, Medical and Pharmaceutical Uses of Seaweed Natural Product: A Review. Journal of Applided Phucology, 16 (4): 245-262.

Sukiman, A. Muspiah, S. P. Astuti, H. Ahyadi, dan E. Aryanti. 2014. Keanekaragaman dan 
distribusi spesies Makroalga di wilayah sekotong lombok barat. Jurnal Penelitian UNRAM, 18 (2): 71-81.

Sunarpi, A. Jupri. R. Kurnianingsih, N. I. Julisaniah, A. Nikmatullah. 2010. Effect of seaweed extracts on growth and yield of rice plants. Bioscience, 2 (2), 73-77. DOI: 10.13057/nusbiosci/n020204.

Diakses Desember 2017.

Wattymuri, D. 2004. Studi Morfologi Makro Alga di Pulau Siladen dan Mantehage. (Tesis) Program

Pascasarjana.UNSRATManado.

Widyastuti, S. 2010. Sifat Fisik Dan Kimiawi Karagenan Yang Diekstrak dari Rumput Laut Eucheuma Cottonii Dan E. Spinosum pada Umur Panen Yang Berbeda. Agroteksos. 20(1): 41-50.

Widyastuti,S. 2008. Eksplorasi spesies alga coklat lokal Lombok sebagai sumber karaginan. Jurnal Teknologi Pertanian, 9. (2): 131-137. 
